\title{
Coordination of sanitation investment decisions with broader water resources management
}

\author{
Coordenação entre decisões de investimento em saneamento e gestão \\ de recursos hídricos
}

\author{
Ana Paula Dalcin' \\ Guilherme Fernandes Marques"
}

\begin{abstract}
Water pollution affects water security, reducing water supply to economic water uses and threatening environmental preservation and human health. Controlling water pollution depends on efforts on two main sectors. One is water management, which provides regulatory instruments, including water quality standards, water abstraction and water discharge permits, as well as economic instruments, like water and wastewater charges. Another is sanitation, which is responsible for expansion of water and wastewater infrastructure and faces challenges in financing extensive infrastructure. While water management defines broader (watershed scale) strategies to address water quality, other decisions regarding infrastructure investments are made by the sanitation sector at the municipality scale, with limited perception of broader watershed context on water availability and pollution. When water management and sanitation decisions are not coordinated there are missed opportunities to (a) meet water quality standards at given river reaches due to lacking investment upstream and (b) find least cost investment solutions across municipalities, at the watershed scale. In this paper, we present methods and solutions to coordinate wastewater infrastructure expansion planning with water management instruments in the long-term planning to maximize economic returns and improve water quality. Our methods identify the regions where investments could be prioritized, coordinated with the distribution of water permits and definition of water quality targets. Results show that restricting water permits on some watershed regions results in a small water availability trade-off for economic uses but a significant reduction in costs to sanitation investments, while also meeting the water quality targets. We conclude that while there are several ways to reach predefined water quality targets, each way requires wellcoordinated decisions from the water management perspective (where and when to allocate water permits) and the sanitation sector (where and when to concentrate investments in wastewater treatment). Thus, as important as the decisions to improve water management instruments and to increase investments in sanitation is their coordination towards a common watershed goal.
\end{abstract}

Keywords: Wastewater infrastructure; Water management instruments; Water security.

\section{Resumo}

A poluição afeta a segurança hídrica ao reduzir a disponibilidade de água para usos econômicos, bem como ameaçar a preservação ambiental e a saúde humana. O controle da poluição hídrica depende de esforços em dois setores principais. Um deles é a gestão da água, que fornece instrumentos regulatórios, 
incluindo o enquadramento e a outorga, bem como instrumentos econômicos, como a cobrança pelo uso da água e lançamento de carga poluente. Outro é o saneamento, que é responsável pela expansão da infraestrutura de água e esgoto e enfrenta desafios diversos quanto ao seu financiamento. Enquanto a gestão da água define estratégias mais amplas (escala de bacia hidrográfica) para lidar com a qualidade da água, outras decisões relativas a investimentos em infraestrutura são tomadas pelo setor de saneamento na escala municipal, com percepção limitada do contexto mais amplo da bacia hidrográfica sobre a disponibilidade de água e poluição. Quando as decisões de gestão da água e saneamento não são coordenadas, perdem-se oportunidades de (a) atender aos padrões de qualidade da água em determinados trechos da bacia devido à falta de investimento à montante e (b) encontrar soluções de investimento de menor custo entre os municípios, na escala da bacia hidrográfica. Neste artigo, apresentamos métodos e soluções para coordenar o planejamento da expansão da infraestrutura de saneamento com instrumentos de gestão da água no longo prazo, a fim de maximizar o retorno econômico e melhorar a qualidade da água. Nossos métodos identificam as regiões onde os investimentos podem ser priorizados de forma coordenada com a distribuição de outorgas e definição de metas de enquadramento. Os resultados mostram que a restrição das outorgas de água em algumas regiões da bacia hidrográfica resulta em um pequeno trade-off na disponibilidade de água para alguns usos econômicos, mas uma redução significativa nos custos de investimentos em saneamento, além de cumprir as metas de qualidade da água. Concluímos que, embora existam várias maneiras de atingir metas predefinidas de enquadramento, cada forma requer decisões bem coordenadas na perspectiva da gestão da água (onde e quando conceder uma outorga) e do setor de saneamento (onde e quando concentrar os investimentos em saneamento). Assim, tão importante quanto as decisões para melhorar os instrumentos de gestão da água e aumentar os investimentos em saneamento é sua coordenação em direção a um objetivo comum na bacia hidrográfica.

Palavras-Chave: Infraestrutura de saneamento; Instrumentos de gestão da água; Segurança hídrica.

\section{Introduction}

Water security is an essential requisite for economic development and inclusive growth (WINPENNY, 2015). With growing water scarcity, the awareness that water supply is affected by both quantity and quality has increased concerns and efforts not just to expand infrastructure and improve management over water supply sources but even to deal with water pollution issues. By freeing water resources for other uses or for preservation, Rodriguez et al. (2020) point out water pollution control as one solution to deal with water scarcity and the problem of water security. Controlling water pollution towards water security depends on efforts on two main sectors. One is water management, which provides regulatory instruments, including water quality standards, water abstraction and discharge permits, as well as economic instruments, like water and wastewater charges. Another is sanitation, which is responsible for the expansion of water and wastewater infrastructure. The latter requires significant 
amount of investments, imposing challenges on the economic agenda/budget of most countries (WINPENNY, 2015). Hutton and Varughese (2016) estimate that the capital investments required to achieve the water supply, sanitation, and hygiene targets of the UN Sustainable Development Goals (SDGs) amount to about three times the current investment levels. In the Latin America and the Caribbean (excluding Uruguay, Chile and some (aribbean countries), the estimate of capital expenditures to meet SDG targets for sanitation represents $0.10 \%$ to $0.38 \%$ of the Gross Regional Product (GRP), of which approximately 95 percent would be devoted to urban areas (HUTTON and VARUGHESE, 2016; RODRIGUEZ et al., 2020).

Many studies have applied optimization approaches in order to find improved treatment portfolio and less expansive solutions for the wastewater infrastructure planning and expansion problem. Zeferino et al. (2010) proposed a model to determine an optimal economic solution for wastewater system design, which includes decisions about layout sewer networks, and the location, type, and size of treatment plants and pump stations. In Zeferino et al. (2012), the previous study was extended by including river flow uncertainty. Rehan et al. (2014) presented a system dynamics model to simulate the influence of interrelationships in wastewater collection network management and investigate financial and rehabilitation strategies. In Naderi and Pishvaee (2017), a stochastic programming model was proposed for the design of integrated water supply and wastewater collection systems, whereas Prouty et al. (2020) developed a system dynamic model to determine portfolio of wastewater technologies and strategies to improve the performance measures (i.e. nutrient loading and reliability) under extreme weather scenarios.

From a water management perspective, it is necessary to decide on water abstraction and wastewater discharge permits, water quality standards, and water charges, which represent examples of regulatory and economic management instruments to deal with pollution control (BRANDT et al., 2017; OECD, 2017). Such management instruments are interconnected and also present financial implications. For example, the definition of water quality standards is tightly associated with water 
availability and it is likely to reflect on other instruments like water permits, which affects both economic returns from water use and wastewater treatment investments to meet the water quality standard. In order to investigate the relationship between water quality and treatment costs, Davidsen et al. (2015) proposed an optimization model to compare the economic impacts of complying with various water quality grades analyzing pollution discharge and water treatment costs. In Martinsen et al. (2019), a water allocation model was proposed to optimize the water delivery to users following quantity and quality requirements while minimizing total costs of groundwater pumping and surface water treatment when the quality of the source did not comply with the quality demand.

While water management typically defines broader, watershed scale, strategies to address water quality, other decisions regarding infrastructure investment are made by the sanitation sector at the municipality scale, with limited perception of broader watershed context on water availability and pollution. When water management and sanitation decisions are not coordinated there are missed opportunities to (a) meet water quality targets at given river reaches due to lacking investment upstream and (b) find least cost investment solutions across municipalities, at the watershed scale. For Rodriguez et al. (2020), implementing wastewater solutions isolated from the river basin planning also reduces the opportunity of creating more resilient systems. Although current literature in the field have explored at length solutions from either the sanitation or water management perspective, there is little work describing how those solutions could be coordinated. More recently, Dalcin and Marques (2020) proposed a method to integrate several water management instruments, which contributed to identify useful directives for their implementation.

This paper builds upon the work on Dalcin and Marques (2020), and explores solutions to coordinate wastewater infrastructure expansion planning with water management instruments in the long-term planning to maximize economic returns and water quality at the watershed scale. By considering hydrological conditions and the interaction between upstream and downstream water uses, the modeling results 
go beyond the local or municipal planning, allowing identification of basin regions where investments could be better prioritized along with water permits and water quality standards implementation. Those results should be useful to sanitation companies in two major aspects. One is to coordinate investments in water and wastewater to both reduce their cost and avoid contamination of each other's supply sources (which increases water supply treatment costs). A second is to prioritize investments in the watershed regions that are most critical according to the watershed plan (for example, regions where the current water quality is the farthest from the water quality standard). From the perspective of the watershed committee and the water management administration body, the results should be useful to provide directives to water management instruments, that could be integrated among themselves and coordinated with the investments in sanitation infrastructure. Combined, all these aspects highlighted in our results will identify innovative coordination opportunities for sanitation and water management decisions at the watershed scale.

\section{Methodology}

\subsection{Study area}

The Sinos River basin is located in the northeast region of the Rio Grande do Sul State, Southern Brazil (figure 1). With a drainage area of $3,696 \mathrm{~km}^{2}$, the basin includes the territory of 32 municipalities with an estimated population of 1,350,000 (PROFILL, 2013). The basin can be divided in three main regions with homogenous hydro and geology features, each divided in sub-basins (UNISINOS, 2010). The main water demand activities are associated to urban supply (35\%), industrial (11\%), and rice irrigation practices (53\%) (PROFILL, 2013). 
Figure 1 - Sinos River Basin

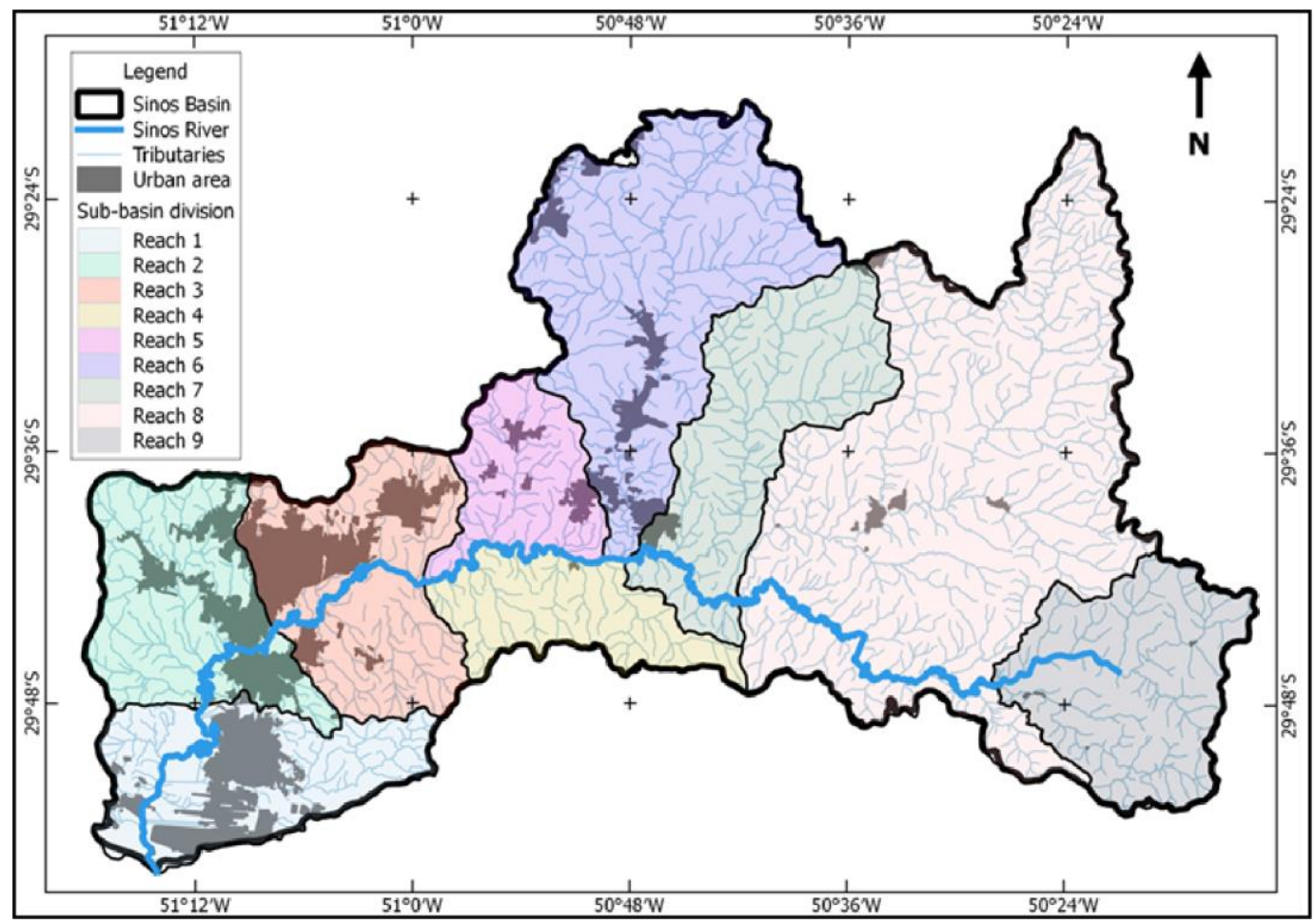

Water bodies are classified according to Brazilian federal law, based on the expected uses of their water (BRASIL, 2005). There are separate classes for water quality and each class has its own upper bounds in concentration of a list of different constituents. The first class is termed "special" and it has the strictest limits, meaning that while the quality is the highest among the other classes, the land use in the watershed draining to this water body is also the most limited. This class is followed by other four, ranging from 1 to 4 (the higher the number, the higher the concentration levels allowed). Class 4 has the highest limits for concentration of constituents and a water body in this class has very few uses aside from navigation. By law, urban water supply systems can only withdraw from water bodies below class 4 . The classification procedure is conducted during the preparation of the watershed plan, with feedback from local users through their representatives in the watershed committee, and takes into account the local users' expectation and desire towards water and environmental quality, as well as water availability for economic development. The classification thus 
defines targets for water quality standards that represent a compromise between water quality and economic water uses.

The Sinos River is current classified as class 4 in its major length mainly due to phosphorous and thermotolerant coliforms concentrations exceeding class 4 thresholds (PROFILL, 2014a). The domestic sewage discharges is the main pollution concern, in which $4.5 \%$ of its total population has sewage collection and treatment system (CONCREMAT, 2014). In order to reduce pollution levels and protect the designated uses, the Sinos river Watershed Plan has stablished water quality targets to the main river (Sinos river) and some tributaries. The target constituents are biochemical oxygen demand (BOD), dissolved oxygen (DO), and thermotolerant coliforms since they represent domestic pollution and also for requiring wastewater treatment solutions that are less expensive if compared to other constituents like phosphorous. Table 1 presents the water quality targets along the Sinos River main channel, which vary from class 1 and 2 in the upper division to class 3 in the medium and lower division. The Sinos River Watershed Plan estimates investments on urban sewage infrastructure amount to about $\mathrm{R} \$ 1.5$ billion for a twenty-year planning horizon in order to mitigate current pollution and meet the proposed water quality targets (PROFILL, 2014b).

Figure 2 represents the sum of all users' observed water demand at each watershed region (reference year 2014 - PROFILL, 2013). The lower watershed ( $n=1$, 2 , and 3 ) is the one with higher water demand due to its strong industrial and urbanization characteristics combined with irrigated rice production. The lower watershed represents $85 \%$ of the total urban water demand, $66 \%$ of the total water demand for irrigated rice production, and $92 \%$ for industrial purposes. The concentrations above water quality targets at all reaches $n$, with exception of reach 8 , indicate that the load emissions are higher than the river depuration capacity at minimum flows (Q90). Under such conditions, there is no water available to dilute additional loadings. Hence, in order to accommodate new users and meet the prescribed water quality targets, it is necessary to reduce the existing pollution levels 
in almost all reaches. An exception occurs at reaches 4 and 5 (at the middle watershed). Although reaches 4 and 5 also have industrial and irrigation water uses, the population is smaller if compared to the other portions of the watershed. As consequence, the pollution concentration is mostly due to wastewater discharges and water withdrawals taking place upstream.

Figure 2 - Representation of the observed water demand by watershed region and observed water quality concentration at the main river

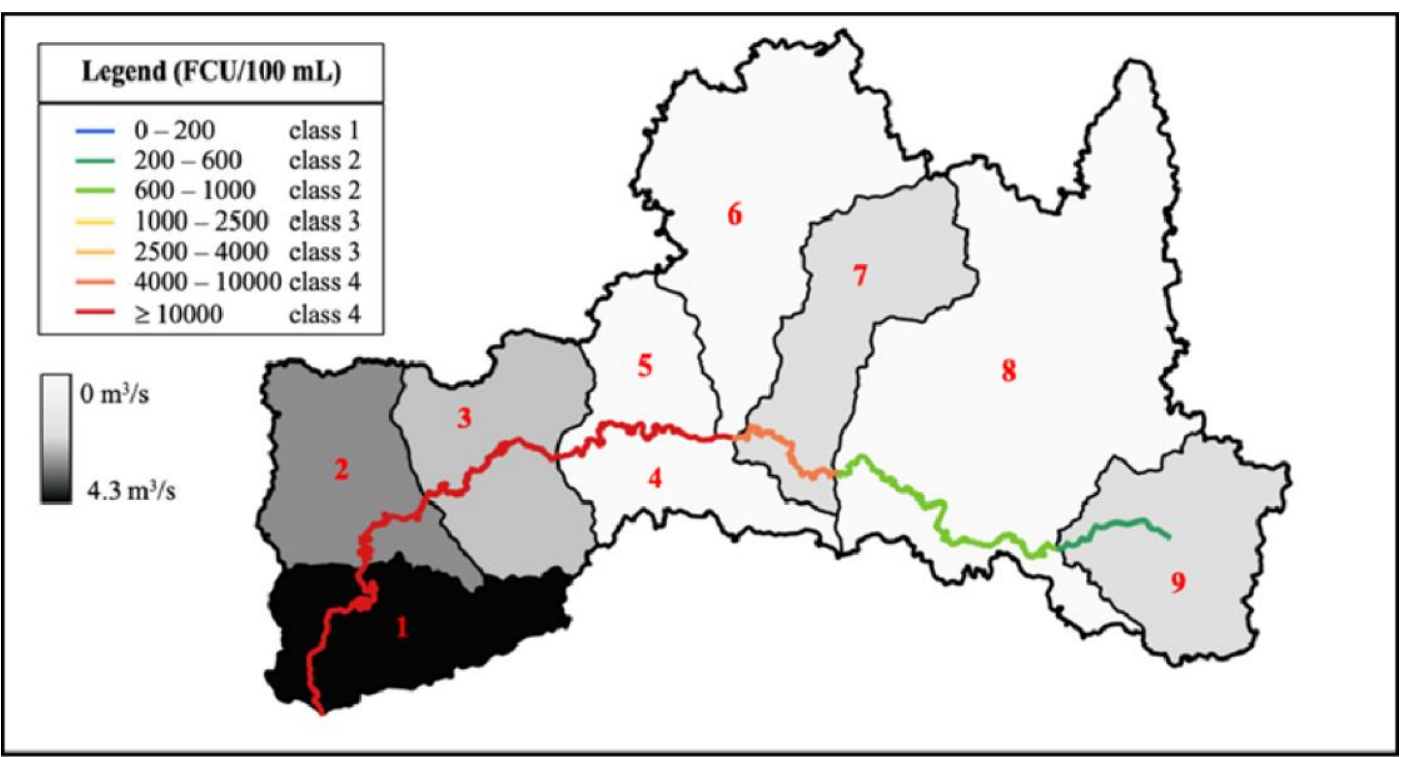

\subsection{The Model}

In order to identify solutions to coordinate wastewater infrastructure expansion planning with water management instruments, water quality simulation is integrated to an optimization model that searches for an economic optimal water allocation strategy for the watershed, considering the economic benefits from water use and the expansion cost of the sanitation infrastructure. The whole integrated optimization model is named VISTA (DALCIN and MARQUES, 2020). The model framework is composed by a main routine that uses dynamic programing algorithm to optimize the distribution of water permits along a planning horizon (divided in stages), following economic development projections and water use preferences (figure 3). Each water permit increment decision has implications on economic benefits generation and 
water pollution control costs. Sub-routine I applies a multi-objective linear programming algorithm (MOLP) to optimally distribute the water permits increments to different water use sectors (economic users and environmental use) and calculates the resulting economic benefits from the water use through economic water value functions. A second sub-routine uses an optimization/simulation water quality algorithm based on a non-linear programming approach to spatially split the water permits of each water use sector over basin regions and calculates wastewater treatment costs to achieve the proposed water quality targets.

Figure 3 - Modelling routine and sub-routines flowchart

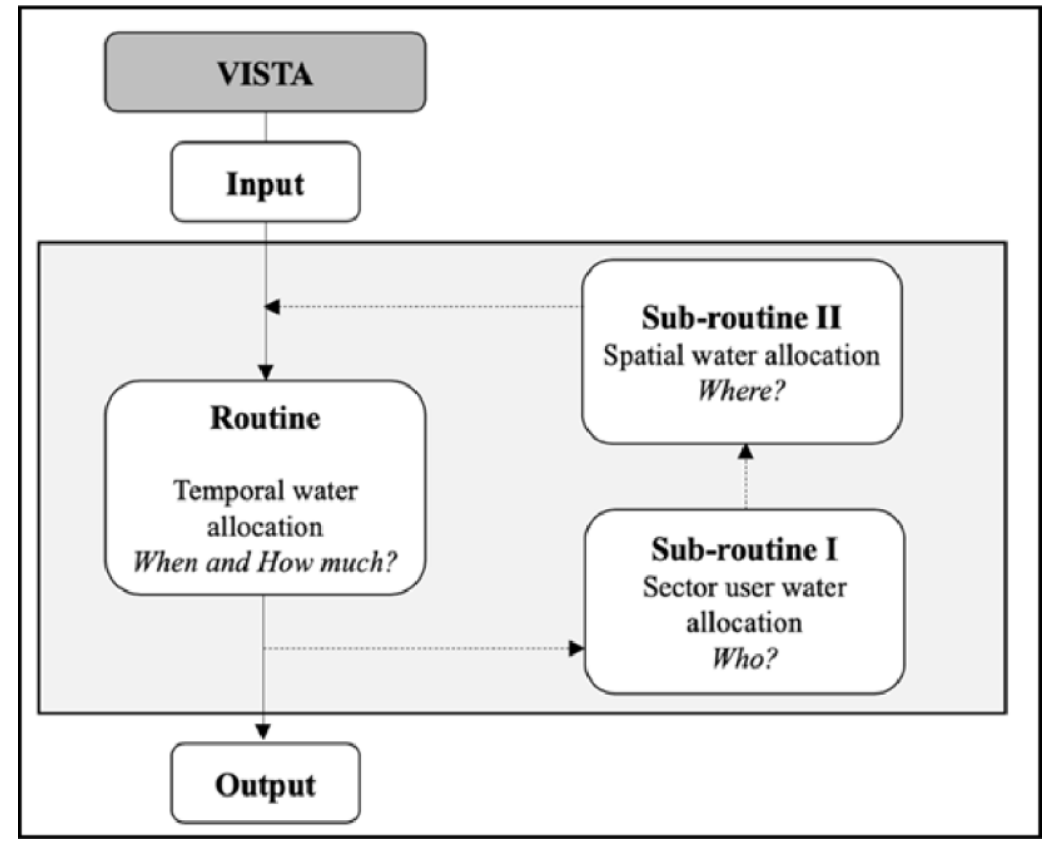

Upstream water use effects downstream water quality conditions and hence its downstream use. Sub-routine II incorporates contaminant mass transport and depuration equations, in which the main river is divided into reaches or control volumes $\mathrm{n}$ with specific flow availability and quality constraints (see Dalcin and Marques (2019) for details). User's withdrawals and discharges are represented as lateral contributions in the transport equation, and all loads located within each control volume are summed and characterized as a single punctual discharge at the end of each volume control (Figure 4). The total load to be removed in order to meet the water quality targets at each stage $t$ and reach $n$, is set as decision variable in the model, 
which is represented by the product of a flow by a concentration removal efficiency of the contaminant modeled. The removal efficiency depends on the wastewater treatment techniques applied (i.e. primary, secondary, tertiary or advanced treatment). While non-point source pollution generated by agriculture can be partially removed through soil management practices (e.g. erosion control), and the costs of those practices could be associated to a removal efficiency and added to the model, we currently lack reliable data to include it in the model, thus it is limited to point source pollution removal through wastewater treatment. We assume that industrial discharges follow the federal and state regulations for constituents' thresholds.

Figure 4 - Division of the main river into control volumes $n$ and mass balance representation for a control volume $n$

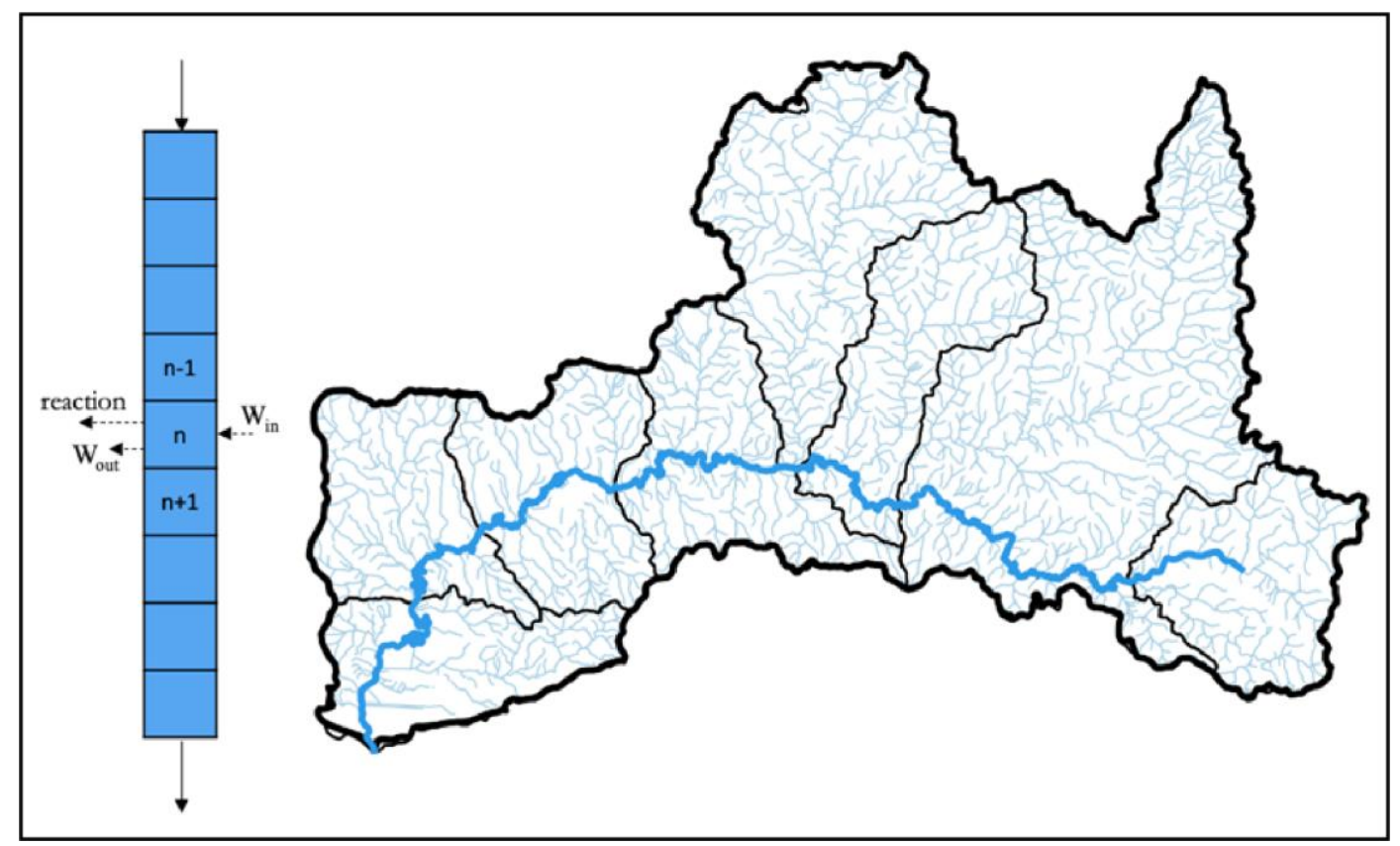

To find the wastewater treatment cost resulting from the modeling load removal, the wastewater flow is then related to a cost value function. The basic residential tariff of the retail company, which includes municipal wastewater collection and treatment, was adopted to compose the value function (CORSAN, 2018). The tariff value considers operational costs and long-term investment recoveries, which is compatible with the long-term planning horizon used in the modeling scenarios. Given most part of the retailer's companies adopts wastewater treatment plants with 
secondary treatment level, we adopted removal efficiency compatible with secondary treatment techniques.

Although the economic water use (e.g. irrigation, urban, industrial) brings higher global economic returns from water use, water use interferes on the water quality (i.e. reducing water dilution capacity, increasing pollutants constituents), requiring higher water pollution control measures. The costs and benefits in sub-routine I and II are calculated separately since the wastewater treatment cost in sub-routine II is an incremental cost, which can only be calculated after spatial allocation of withdrawals and discharges are determined based on hydrological conditions and water quality targets. All costs and benefits from sub-routines I and II are then relayed back to the main routine, in which modeling economic benefit results (economic benefits from water use minus water pollution control costs) allow to investigate optimized water allocation strategies. For example, it shows where water permits should be restricted and where water quality targets can be adjusted considering water pollution control costs and the economic water value.

\subsection{Modeling scenarios and projections}

The model was run for three scenarios with a 20-year planning horizon, divided in 4 stages of 5 years each. The scenarios represent different users' preferences towards environmental quality and economic development at each stage of the planning horizon. Here, economic preferences mean more water allocated to economic uses (i.e. urban, agricultural, and industrial), while environmental preferences denote more water allocated to environmental demands and ecosystem protection. These preferences also define local water policies and boundary conditions to the model, hence testing different preferences is also a way to include other dimensions of water management, in the form of which water preferences should be fostered along the time horizon.

In scenario A, the economic use of the water (water permits incrementation) is prioritized along the planning horizon. This represents maintenance of a business-as- 
usual condition, where water is allocated exclusively based on its availability, without consideration of the externalities from its use (e.g. pollution) and its economic value to users. In scenario $C$, the water protection is prioritized by restricting the incremental allocable flow to economic uses and leaving more water in the streams (which may constrain water availability to meet economic growth). This represent an abrupt departure from scenario $A$, with more focus on environmental protection and river water quality, at the expense of economic water demands. Finally, scenario $B$ is a mix between the economic water use preference and environmental protection. In the first stages the water permits increments' decision follows economic priorities, while for the remaining stages it switches to higher priority to environmental protection. This represents a gradual change from a business-as-usual condition (scenario A) to an environmentally focused condition (scenario C).

Given our focus is to find decisions coordinating wastewater infrastructure expansion with water management instruments, the following decisions are considered. From the perspective of water management, it must be decided: (a) How many water permits should be issued, when and where; (b) How strict should be the water quality targets and where; and (c) Which scenario should be pursued. From the perspective of sanitation, it must be decided: (a) Load removal from each site, and (b) How much to invest in infrastructure, when and where.

We consider the three main water use sectors of the study basin (irrigated agriculture, urban supply, and industrial use) as economic uses plus the environmental use representing preservation and river protection. The 20-year planning horizon includes economic, water demand growth and population projections based on available census data followed data projections. The urban sector considered an annual average growth of $1.1 \%$, the industrial sector an annual growth rate of $2.4 \%$, and the irrigated agriculture with an annual growth rate of $1.25 \%$. Intermediate water quality targets were defined for each stage along the planning horizon in the model before meeting the final ones (table 1), and the incremental water permits were based on the available allocable flow following the current water permitting criteria, which 
allows up to $70 \%$ of $Q_{90}\left(14.04 \mathrm{~m}^{3} / \mathrm{s}\right)$ to be allocated for consumptive users (PROFILL, 2014b). Finally, thermotolerant coliforms were used as the parameter for water quality simulation in sub-routine II.

Table 1 - Water quality classification and final water quality targets applied to the study

\begin{tabular}{lcccc}
\hline $\begin{array}{l}\text { Main river } \\
\text { division }\end{array}$ & $\begin{array}{c}\text { River } \\
\text { reach }\end{array}$ & $\begin{array}{c}\text { Water quality } \\
\text { classification }\end{array}$ & $\begin{array}{c}\text { Water quality } \\
\text { targets }\end{array}$ & $\begin{array}{c}\text { Reach length } \\
\mathbf{( k m )}\end{array}$ \\
\hline \multirow{3}{*}{ upper } & 9 & 2 & 1 & $198-168$ \\
& 8 & 2 & 2 & $168-138$ \\
medium & 7 & 4 & 2 & $138-108$ \\
& 6 & 4 & 3 & $108-97$ \\
& 5 & 4 & 3 & $97-86$ \\
lower & 4 & 4 & 3 & $86-75$ \\
& 2 & 4 & 3 & $75-50$ \\
& 1 & 4 & 3 & $50-25$ \\
\hline
\end{tabular}

\section{Results and Discussion}

Figure 5 shows the regions where higher investments in infrastructure must be done in other to achieve the prescribed intermediary and final water quality targets. The investments are for treating both the existing pollution and the pollution resulting from the allocation of new water permits along the planning horizon (the darker the shaded area, the higher the wastewater flow treated). The maps are organized by scenario and stage. For each scenario, it is possible to visualize the wastewater treatment flow increments at each stage $t$ together with the resulting water quality concentration at each reach $n$, depicted by the color of the river line.

For all scenarios, the lower watershed (reaches 1,2 and 3) is the one that requires the highest wastewater treatment investments, mainly due to the concentration of urban demands combined with very limited sewage collection and 
treatment infrastructure. Despite the concern with high pollution, these reaches are still more favorable to the allocation of new water permits, since the backwater effect at the river mouth (Jacuí delta) reduces the hydraulic speed and contributes to increase the auto depuration capacity of the reaches 1 and 2 .

In scenario A, where the preferences are strongly economic, the resulting water permit allocation meets most of the economic projected water demand (82\% for irrigation, and $100 \%$ for urban and industrial sectors), resulting in an economic benefit increment of $\mathrm{R} \$ 4,666$ million (over the 20-year planning horizon). This scenario also results in the highest investment in wastewater treatment compared to the other scenarios, achieving $2.52 \mathrm{~m}^{3} / \mathrm{s}$ at a total wastewater treatment cost increment of $\mathrm{R} \$ 959$ million (over the 20-year planning horizon) if the water quality targets are to be reached. At the lower watershed (reaches 1, 2 and 3), the load removal follows the allocation of new water permits to industrial and irrigated agriculture sectors, combined with incremental wastewater improvements to treat the existing pollution and meet the intermediate water quality targets. No allocation of new water permits occurs at the middle watershed (reaches $4,5,6)$ so that this region only depends on the upstream reaches resulting quality. For the upper watershed, reaches 8 and 9 achieve the final water targets at the first stage but they need incremental wastewater treatment along the planning horizon due to the allocation of new water permits to urban users.

For the urban sector, the allocation of new water permits is constrained by the user's water quality requirements. No new urban demand can withdraw water if the river has water quality class above 3. However, the current water permits for urban sector are maintained even if the reach is classified as class 4 , since VISTA just considers new incremental flow allocation (although the current regulation imposes this restriction, withdrawals at class 4 is a common reality in most part of the urban regions of Brazil). Another consideration here regards the water quality modeling limitation. The spatial allocation sub-routine considers the impacts of all withdrawals and discharges in the main river channel only (tributaries are not modeled). Although the 
water for urban use may be withdrawn from a tributary classified under a lower class, this limitation is attenuated by the fact the main tributaries of the lower watershed are current also classified as class 4 and the effects are still persistent in the main channel. As the intermediary water quality targets of the upper watershed (reaches 7, 8, 9) meet urban requirements before the lower watershed (the lower watershed achieves class 3 only at the last stage), those are more favorable to receive new water permits to urban use, and thus some water permits are allocated to regions in the upper watershed. This result shows the relation between water quality and water supply, and its economic implications. The lower watershed has better water availability conditions to receive new urban water permits. However, due to water pollution, water supply can be affected. It does not mean that water supply must be restricted in the lower reaches but if done so it will bring in higher costs.

For Scenario B, which represents a gradual shift to water policies with increasing preference for environmental quality, the allocation of new water permits is reduced, falling behind the projected water demand by a larger margin if compared to scenario A. Irrigated agriculture has $20 \%$ of its demand unmet and the urban sector has $8 \%$ of its demand unmet, resulting in an economic benefit increment of $R \$ 4,658$ million (over the 20-year planning horizon). However, scenario B also demands smaller investment in wastewater treatment compared to scenario $A$, as less wastewater is being produced ( $2.29 \mathrm{~m}^{3} / \mathrm{s}$ representing a total wastewater treatment cost of $\mathrm{R} \$ 905$ million). This can be verified in the upper watershed, in which scenario $B$ achieves the same water quality concentration as scenario A, but with less investment in wastewater treatment due to its smaller water abstraction and wastewater discharges by users.

For Scenario C, most of the investment in wastewater treatment must be done to remove the existing pollution. This sanitation sector decision reflects the water management decision to significantly reduce allocation of new water permits following a more environmental water use preference (resulting in a lower economic benefit increment of $\mathrm{R} \$ 3,969$ million over the 20-year planning horizon). As a result, the river depuration capacity increases, along with less wastewater discharges to be treated. 
The wastewater treatment flow is $2.01 \mathrm{~m}^{3} / \mathrm{s}$, which brings the total cost of new wastewater infrastructure from $\mathrm{R} \$ 959$ million in Scenario $A$ to $R \$ 759$ million in scenario C.

Figure 5 - Load removal required and water quality concentration improvements

Scenario A scenario B

The darker the shaded area, the higher the load removal and the necessary investment in wastewater treatment. For the river: red - class 4; orange - class 3, green - class 2, blue - class 1.

These results show that it is possible to find least cost solutions for investment in sanitation and also meet prescribed water quality targets. Scenario B represents the 
best resulting economic benefit of $R \$ 3,753$ million (economic benefit minus wastewater treatment costs). However, each solution requires coordinated decisions on how to allocate water permits (water management) and how to allocate wastewater investments (sanitation). In order to find such coordination, the analysis needs to integrate economic implications (both in terms of the economic value of the water and deal with the externalities of using it) and water management instruments (e.g. water quality targets and water permits) like it was presented here.

Finally, modeling results allow to identify different measures (as regulations economic instruments and decisions from the sanitation sector) that can be implemented to achieve the resulting optimal strategy, such as: (a) Improved water conservation measures to allow curtailment of new water permits; (b) more restrictive effluent discharges thresholds in order to mitigate the resulting elevation of the pollution and reducing of the dilution capacity at some river reaches, and (c) more restrictive water charges for water withdrawal or effluent emission thresholds could also be imposed at these regions in order to induce rational use and improve the efficiency of the water use and load removal efficiency. The sanitation sector can contribute to those strategies by increasing investment in loss reduction and other water conservation programs, adjusting block tariffs to motivate users to invest in more efficient water fixtures. The upper and middle watershed are good examples where efficient use of water should be prioritized. To allow irrigation expansion at these regions, water efficient use requirements should be imposed so that the curtailment on the new water permits would be mitigated by the water saved through application of such requirements. Similarly, the installation of new industries in some regions should require more restrictive effluent discharges thresholds in order to mitigate the resulting elevation of the pollution and reducing of the dilution capacity. More restrictive water charges for water withdrawal or effluent emission thresholds could also be imposed at these regions in order to induce rational use and improve the efficiency of the water use and load removal efficiency. 


\section{Conclusion}

We conclude that while there are several ways to reach predefined water quality targets, each way requires well-coordinated decisions from the water management perspective (where and when to allocate water permits) and the sanitation sector (where and when to concentrate investments in wastewater treatment). Thus, as important as the decisions to improve water management instruments and to increase investments in sanitation is their coordination towards a common watershed goal. When these decisions are aligned, the goals (in this example water quality targets) can be reached at lower costs and water can be more efficiently allocated in the watershed, avoiding conflicts and watershed "closures" (when no more water permits can be issued).

To identify such coordination opportunities, it is important to first define priorities regarding water pollution control and preservation, followed by optimization of investments combined with the economic value of the water to different users across the watershed. Allocating new water permits at some regions may cause higher impacts on the water quality, requiring higher wastewater treatment investments in order to achieve water quality targets. Hence users may decide if it is worthwhile to use more water (which has economic benefits), to conserve it and reduce the burden to the sanitation sector, (which has financial benefits) or to relax the water quality targets (which has environmental costs beyond economics). Only when the economic implications are considered one can identify the tradeoffs among those possibilities and derive long term coordination solutions to integrate sanitation and water management that are less costly to users and environmentally better.

\section{Acknowledgements}

The authors thank the Federal University of Rio Grande do Sul, CAPES for the financial support and CNPq for support through grant 308549/2019-9. 


\section{References}

BRANDT, M. J. et al. Water Supply Regulation, Protection, Organization and Financing. In: Twort's Water Supply. 7. ed. USA: Iwa Publishing, 2017. p. 37-63.

BRASIL. Resolução CONAMA 357. Brasília, DF, Brasil: Ministério do Meio Ambiente, 2005.

CONCREMAT. Plano regional de saneamento básico: relatório do diagnóstico. Porto Alegre, Brazil: Prosinos, 2014.

CORSAN. Estrutura tarifária sintética - consórcio Pró-Sinos. Available from: http://www.corsan.com.br/sistematarifario. Access on: 11 dez. 2018.

DALCIN, A.; MARQUES, G. Simulação da qualidade da água para suporte em modelos de otimização para planejamento e gestão de recursos hídricos. Revista de Gestão de Água da América Latina, v. 16, n. 1, p. 15-15, 31 dez. 2019.

DALCIN, A. P.; MARQUES, G. F. Integrating water management instruments to reconcile a hydro-economic water allocation strategy with other water preferences. Water Resources Research, p. e2019WR025558, 14 abr. 2020.

DAVIDSEN, C. et al. Hydroeconomic optimization of reservoir management under downstream water quality constraints. Journal of Hydrology, v. 529, n. 1, p. 1679-1689, 2015.

HUTTON, G.; VARUGHESE, M. The Costs of Meeting the 2030 Sustainable Development Goal Targets on Drinking Water, Sanitation, and Hygiene. Washington, D.C., USA: World Bank, 2016.

MARTINSEN, G. et al. Joint optimization of water allocation and water quality management in Haihe River basin. Science of the Total Environment, v. 654, p. 72-84, 2019.

NADERI, M. J.; PISHVAEE, M. S. A stochastic programming approach to integrated water supply and wastewater collection network design problem. Computers and Chemical Engineering, v. 104, p. 107-127, 2017.

OECD. Water Charges in Brazil: The Ways Forward. Paris: OECD Publishing, 2017.

PROFILL. Plano de Bacia do Rio dos Sinos: Relatório final RT1 Fase inicial e Fase A. Porto Alegre, Brazil: Profill engenharia e ambiente LTDA, 2013. Available from: http://www.comitesinos.com.br/planodebacia. 
PROFILL. Plano de Bacia do Rio dos Sinos: Relatório técnico 2 - RT2 Fase B complementação do enquadramento. Porto Alegre, Brasil: Profill engenharia e ambiente LTDA, 2014a. Available from: http://www.comitesinos.com.br/planodebacia.

PROFILL. Plano de Bacia do Rio dos Sinos: Relatório final RT3 Fase C - programa de ações. Porto Alegre, Brasil: Profill engenharia e ambiente LTDA, 2014b. Available from: http://www.comitesinos.com.br/planodebacia.

PROUTY, C.; MOHEBBI, S.; ZHANG, Q. Extreme weather events and wastewater infrastructure: A system dynamics model of a multi-level, socio-technical transition. Science of the Total Environment, v. 714, p. 136685, 2020.

REHAN, R. et al. Financially sustainable management strategies for urban wastewater collection infrastructure - development of a system dynamics model. Tunnelling and Underground Space Technology, v. 39, p. 116-129, 2014.

RODRIGUEZ, D. J. et al. From Waste to Resource: Shifting Paradigms for Smarter Wastewater Interventions in Latin America and the Caribbean. Washington, DC, United States: World Bank, 2020.

UNISINOS. Plano de Gerenciamento da bacia hidrográfica do Rio dos Sinos: Atividade 3.3 - síntese da situação atual dos recursos hídricos. Porto Alegre, Brazil: 2010. Available from: http://www.prosinos.rs.gov.br/publicacoes-legais/acervo-bibliografico/plano-debacia.

WINPENNY, J. Water: fit to finance? Catalyzing national growth through investment in water security. n. April, p. 127, 2015.

ZEFERINO, J. A.; ANTUNES, A. P.; CUNHA, M. C. Multi-objective model for regional wastewater systems planning. Civil Engineering and Environmental Systems, v. 27, n. 2, p. 95-106, jun. 2010.

ZEFERINO, J. A.; CUNHA, M. C.; ANTUNES, A. P. Robust optimization approach to regional wastewater system planning. Journal of Environmental Management, v. 109, p. 113122, out. 2012. 